PEOPLE: International Journal of Social Sciences

ISSN 2454-5899

Dorina Sandu, 2022

Volume 7 Issue 3, pp. 104-119

Received: 29th April 2021

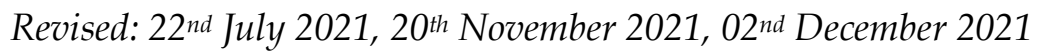

Accepted: 31 ${ }^{\text {st }}$ December 2021

Date of Publication: 07th January 2022

DOI- https://doi.org/10.20319/pijss.2022.73.104119

This paper can be cited as: Sandu, D. (2022). Local Taxes Between Obligation and Fiscal Citizenship. PEOPLE: International Journal of Social Sciences, 7(3), 104-119.

This work is licensed under the Creative Commons Attribution-NonCommercial 4.0 International License. To view a copy of this license, visit http://creativecommons.org/licenses/by-nc/4.0/ or send a letter to Creative Commons, PO Box 1866, Mountain View, CA 94042, USA.

\title{
LOCAL TAXES BETWEEN OBLIGATION AND FISCAL CITIZENSHIP
}

\section{Dorina Sandu}

PhD, Doctoral School - Management, Bucharest University of Economic Studies, Bucharest, Romania dorianasandu@googlemail.com

\footnotetext{
Abstract

The fiscal compliance of the taxpayer reported in percentages regarding the realization of the receipts exceeds in meaning the payment of an obligation established at the level of fiscal policy. As an individual or an entity, the citizen-taxpayer transfers sums of money in the form of tax, but this transfer has in addition to the historical-economic-legislative component and a defining psycho-social one for what we call fiscal citizenship. Visible only in the voluntary fulfilment of fiscal obligations, less in positive attitudes and beliefs, perceptions, motivation, and trust in local authorities, fiscal citizenship remains the barometer of the citizen-public administration or public service relationship. Fiscal citizenship and its defining elements can indicate the extent to which citizens feel defended by democracy and the rule of law. It cannot strengthen fiscal citizenship without strengthening trust in public authorities in terms of fiscal policy and taxation, without the responsibility for the efficient use of the amounts collected, without considering the taxpayer in a threefold way: partner, beneficiary, and client of the local public tax service. A culture based on
} 
rights and responsibilities or the reciprocity of responsibility and the empowerment of the citizentaxpayer is needed.

\section{Keywords}

Public Administration, Civic Duty, Fiscal Citizenship, Fiscal Compliance, Tax Policy, Partnership

\section{Introduction}

With a history as long as that of human communities, local taxes have gone through a long process of historical and fiscal transformations from the simple collection of gifts in kind, the performance of work and services, to monetary contributions.

Socio-economic development is a remarkable process, but impossible without incurring public expenditures financed mainly from taxes. The impact of taxation on taxpayers, far from being felt to be positive at least psychologically and financially, is under the sign of obligation, less of the efficiency, fairness of this levy which is based on the declaratory principle.

Citizens are the ones who declare the elements necessary to establish the tax base, the tax administration having the task of verifying the accuracy of the data in the declarations submitted.

The development of the state over time has been influenced by how solutions have been found for its financial needs.

On the Romanian territory, since the time of the Roman domination in Dacia, it can talk about the taxation system, fiscal officials - judex fiscal, direct and indirect taxes, classification present even today (Dincă, 2013). From the etymological point of view, there are two explanations of the term, both coming from the Latin language - impositum, equivalent to public obligation, and the second - imponere means to impose, to establish by force.

Combining the two explanations, it comes to "impose a public obligation", but the payment of taxes is a civic act, socially responsible behavior that guarantees personal benefits, social protection, access to public services. Cathelineau (1994) pointed out the increasingly prominent place of local taxes and fees in the administrative and fiscal system. Decentralization entailed higher costs for local communities, and their financial resources determined the real degree of their independence from the state. In short, notes the above-mentioned author, the collection of local taxes becomes a fundamental condition of their free administration. The question is how many taxpayers perceive the payment of taxes as a justified civic act, how many consider balanced or 
excessive the amount of these obligations if they are tempted by the advantages or disadvantages of this financial effort or consider fiscal policy a lever to reduce inequalities.

It must be mentioned that today, more than ever, "we are witnessing a major change in the organization of public financial systems and this change is developing in the world as a shock wave that is gradually spreading" (Bouvier, Esclassan \& Lassale, 2020).

The succession of socio-economic crises of the last two decades, especially at the end of 2020, has unbalanced local budgets and the state budget. We found ourselves in totally different situations than those so far, difficult to manage, situations that have increased the degree of distrust and suspicion in the capacity of local and central public administration representatives. The health crisis has transformed the entire socio-economic and political system into a system of the state of emergency.

Defined in the specialized works as a compulsory non-reimbursable levy and without consideration made by the local administration, the tax is an essential instrument of the economic and financial policy of the state, and the destination is to satisfy some needs of public interest. The negative view of how the amounts collected are used and the criticism of fiscal policy have in common a strong belief in the lack of fairness or responsible use.

Although the conceptual framework of taxation seems easy to establish, a much more difficult and interesting aspect at the same time is that of the taxpayer's attitude towards taxation, fees, policies, and tax authorities. Tax collection has never been viewed positively. It is an indicator of the tensions between the individual and the public tax institutions, between the individual and the community to which he belongs, between the individual and the social groups that own the wealth (Dubois, 1972). They are not seen as a necessity but as an obligation; they are not assimilated as the object of a partnership because there is no possibility of negotiation (Lambert, 2013). Paying taxes is a key component of the citizen-public administration relationship. Lack of information and involvement erodes trust in public authorities and blocks the cultivation of good citizenship based on rights and responsibilities. The prompt and voluntary payment of tax obligations is linked to the image of the public institution. It is desired a positive relationship between the tax administration and the taxpayer citizen. To have it, it must be built by informing the taxpayer about the obligations and rights alike, offering the possibility to participate in debates on the most efficient use of the amounts collected. 
The tax compliance of the taxpayer reported in percentages regarding the realization of the receipts exceeds in meaning the payment of an obligation established at the level of fiscal policy.

Fiscal citizenship is essential "a social contract between the state and a class of actors, a contract by which rights are changed into obligations in the form of fiscal obligations" (Freund, 2019). The imbalance between obligation and rights undermines credibility in the state's fiscal policy.

\section{Literature Review}

As an individual or an entity, the taxpayer transfers sums of money in the form of tax, based on current legislation, but this transfer (which may also have negative values in the sense of tax non-compliance) has in addition to the historical-economic-legislative component and a defining psycho-social one for what we call "fiscal citizenship". Allingham \& Sandmo (1972) consider that the payment of taxes and fees is determined by the taxpayer's fear of not being sanctioned by the state, therefore the fear of enforcement is defining the fiscal behavior. However, this argument is not supported by Torgler \& Murphy, 2004 who noted the existence of states where the application of sanctions is extremely low and yet the degree of tax compliance is extremely high.

Visible only in the voluntary fulfilment of fiscal obligations, less in positive attitudes and beliefs, perceptions, motivation, and trust in local authorities, fiscal citizenship remains the barometer of the citizen-public administration or public service relationship. McGee (2006) emphasizes that at the behavioral level are defining the experiences and perceptions of the citizen regarding the institution of taxation and public tax authorities. Unpleasant experiences, their negative perceptions determine the non-compliance with taxes, the obligation to pay them, being the equivalent of punishment applied to the state for its unsatisfactory behavior. Some external and internal factors affect the decision to comply with taxpayers. The personal interest, the extent to which taxes are perceived as fair, the knowledge of taxation or the destination of the amounts collected, certain demographic characteristics may influence the attitude of taxpayers, the decision to accept and participate in them. Self-interest has a decisive effect, and it is advisable to pre-test potential changes in fiscal policy to be able to observe to what extent there are benefits or the impact of these changes (Katz\&Ott, 2006).

It is desired that the taxpayer be seen as a partner in the decision-making process at the local level and beyond. The partnership means first of all the creation of a relationship on an equal 
footing, interaction, common interests, common values, common problems, connection, team, continuity. At this moment, beyond the financial dimension of this relationship, we do not identify much else.

The question What exactly blocks the realization of the tax administration - taxpayer partnership?!? becomes natural. Lack of skills of decision-makers and civil servants, legislative instability? Awareness of citizens? Absence of tax education? What influences the willingness of citizens to pay taxes in a different way than under the pressure of the word must or the phrase $I$ have no choice and why the payment of tax obligations is not a positive experience?!?

\section{Research Issues}

Trying to answer these questions, I set as my general objective of this research the identification of key elements of strengthening the relational-managerial and socio-psychological dimension of fiscal citizenship, and as specific objectives to identify the degree of understanding of fiscal citizenship, the presence of this attitude in behaviour fiscal compliance, identification of the braking factors of the achievement of the taxpayer-local tax administration partnership. I formulated a series of questions starting from the following hypotheses:

- A better understanding of citizens' motivation to comply or not with tax obligations can determine the efficiency and responsiveness of the tax system

- If the tax system is perceived as fair and efficient, the degree of tax citizenship is higher

- The conviction that the establishment of local taxes is made according to the needs of the taxpayer and the community determines the manifestation of fiscal citizenship as a right and not as an obligation

The visibility of the redirection of local taxes to objectives of local interest lays the foundations of a real partnership citizen-local public institution

\section{Methodology}

To carry out the research, I considered a series of works from the specialized literature, but also the application of a self-addressed questionnaire. Among the works studied I mention Toader, 2013; Zai, 2014; Ranta, 2016; Gilbert, 2001; Bouvier, 2019; Ghazali \& Benkendil, 2020; Spire, 2018; Similien, 2017 etc. 
The population included in the research universe is represented by several 120 taxpayers coming from both urban and rural areas. Depending on the subject of the topic approached and the objectives pursued, we established the following units of analysis and registration: individuals 90 subjects (75\%), legal entities - 30 subjects (25\%); depending on the type of subjects they are $45.83 \%$ male gender, $54.16 \%$ - female gender. $54.16 \%$ of the subjects have secondary and postsecondary education, and $45.83 \%$ have higher education. Compared to the area of residence, the subjects come from $58.33 \%$ from the urban area, $41.66 \%$ from the rural area.

Figure 1: Structure Of The Lot Of Subjects Depending On The Environment Of Residence

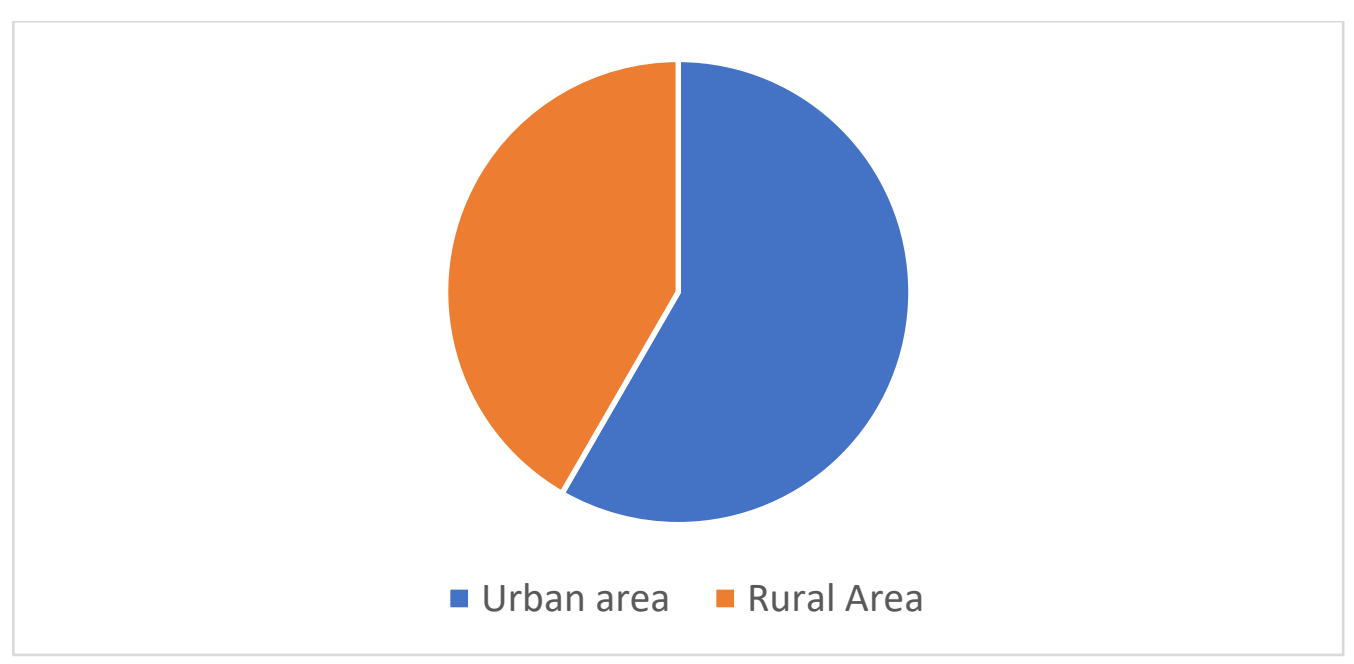

(Source: Authors Own Illustration Based on Chelcea, 2001)

The main concepts used in the research were: local tax, taxation, fiscal citizenship, tax liability, taxpayer, public interest, public institution. The self-addressed questionnaire had several 8 items, the last one containing identification data of the respondents. Some of the questions were pre-coded, of dichotomous or triatomic type. For those who aimed at attitudes and opinions, I preferred questions with several answer options, ranked by rank. I also used scaled and mixed (semi-open) questions to give subjects more freedom in formulating answers.

\section{Analysis}

The first question of the questionnaire aimed at identifying the period in which the subjects had and have the quality of local taxpayer, starting from the idea that having this quality for a longer period, the subject can provide much more assumed answers. 
Following the analysis of the answers, I obtained the following results: $12.50 \%$ of the subjects have experience of paying the financial obligations for a period between 1 and 5 years; $16.66 \%$ have been doing this for 6 to 10 years. For the subjects paying local taxes between $11-15$ years old, I registered a percentage of 25, and for the last group (over 15 years old) the percentage is 45.83. As almost half of the respondents exceed the threshold of 15 years and if I add the $25 \%$ of the previous group, I get 70.83 - a percentage sufficient to consider the significant lot for the proposed research.

Figure 2: Quality Of Taxpayer And Period Of Tax Obligations Payment

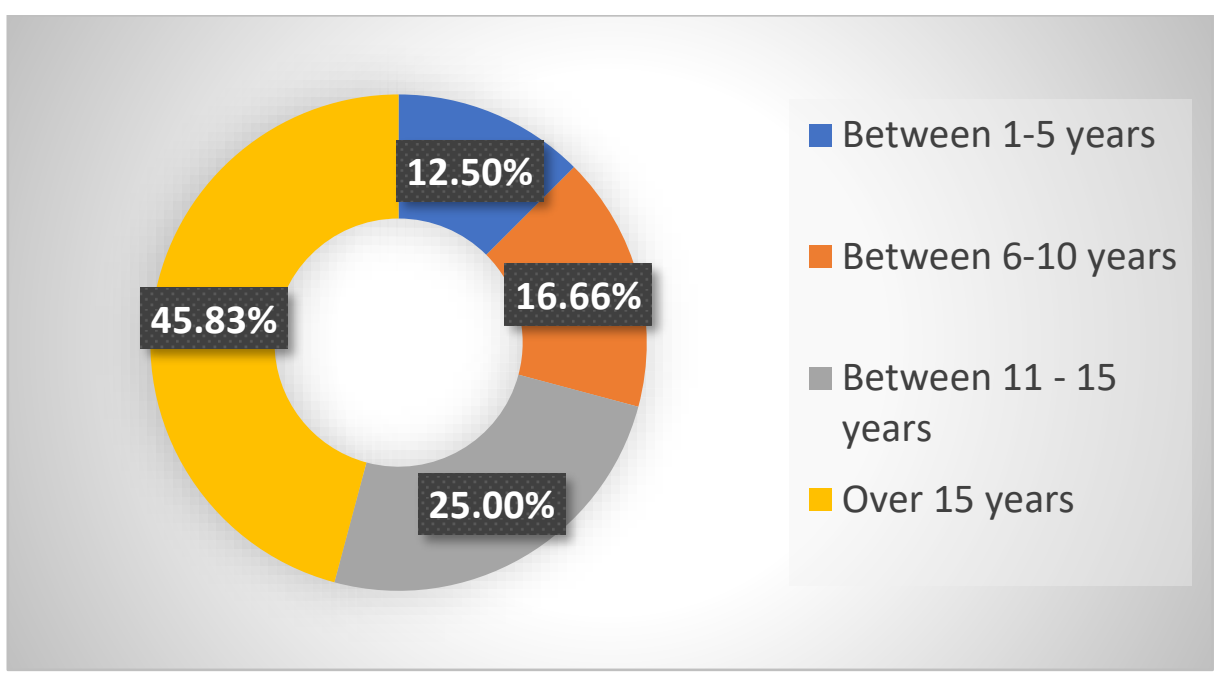

(Source: Authors Own Illustration Based on Chelcea, 2001)

I have corroborated item 2 (From your point of view, local taxes and their payments are a right / an obligation / both / do not know/do not answer) with item 6 (If the contribution would be voluntary, would you still pay?) to identify respondents' perceptions of local taxes and the trend of tax non-compliance.

According to the requirement of item 2, the following answers can be centralized: $4.16 \%$ consider their tax and payment a right, $83.33 \%$ - an obligation, both answers were present in the choice of $12.50 \%$ of the respondents. The obligatory nature of the tax in the perception of the participants in the study is far from observable, and when you perceive the role of the tax as such, there is not much room to strengthen extrinsically motivated participation in the tax system or to strengthen the link between taxpayer and local tax administration. The impact of the obligation also has its impact on tax compliance.

If the payment of taxes would no longer be mandatory and would be a voluntary contribution (item 6), only $16.66 \%$ of respondents would pay their tax obligations, $58.33 \%$ would 
no longer contribute, and $25 \%$ chose the don't know/don't answer option, which means a fairly small percentage of subjects for whom taxes mean development or financing for local community development and that there is still a long way to go to understand the benefits of tax compliance and the need for cultivation fiscal citizenship. Prak \& van Zanden (2013) observed that people generally don't like to pay taxes, but they appreciate the public services received in return: education, hospital treatment, maintaining public order, public transport, street lighting, maintenance of public spaces. They considered that there is a direct link between fiscal citizenship and decision-making transparency: where there is transparency, the degree of fiscal citizenship is high.

A possible explanation could be found by analyzing the answers to items 3 (Regarding the amount of local taxes you pay annually, you can say you are very satisfied/ satisfied/quite satisfied/to some extent satisfied/not at all satisfied/I don't know/do not answer), item 4 (Are you convinced that the determination of local taxes is made taking into account the needs and interests of taxpayers and the community?), and item 5 (At the level of fiscal policy, consider fair and efficient taxation?). The respondents' satisfaction with the amount of local taxes is as follows: $29.16 \%$ say they are very satisfied and satisfied, $41.66 \%$ are quite satisfied and to some extent satisfied, not at all satisfied declare $25 \%$, and $4.17 \%$ chose the option I don't know/don't answer.

Figure 3: Degree of Satisfaction Regarding the Annual Amount of Local Taxes

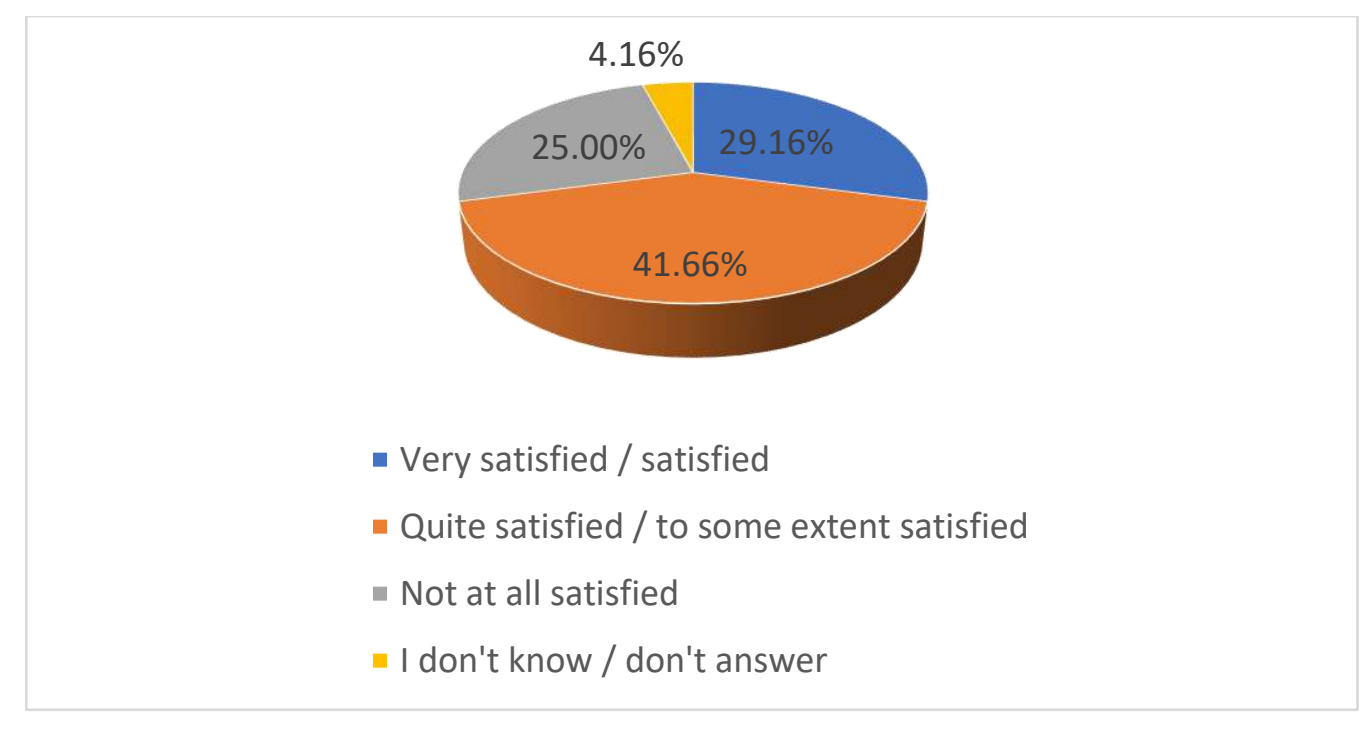

(Source: Authors Own Illustration Based on Chelcea, 2001)

Almost a third of the respondents said they were very satisfied/satisfied; those who chose the average level are much more numerous, but the percentage of the least satisfied (25\%) is not 
to be neglected either, which highlights a dynamic relationship between the degree of satisfaction and the possibility of consolidating fiscal compliance.

For item 4 I registered the following answers: $16.66 \%$ are convinced that the establishment of local taxes is based on the needs and interests of taxpayers/community; a significant percentage, 66.66 do not agree with this statement. and $16.66 \%$ preferred the I don't know/don't answer option.

Figure 4: Agreement on The Establishment of Taxes According to The Needs of

\section{Taxpayers / Community}

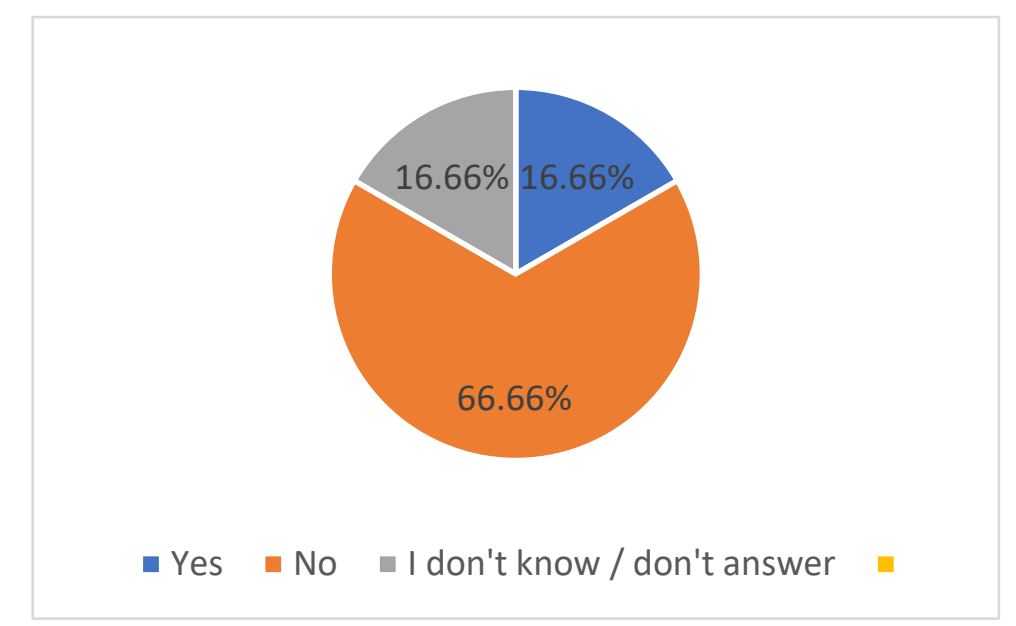

(Source: Authors Own Illustration Based on Chelcea, 2001)

Figure 5: Taxpayers Agreement on Fair and Efficient Taxation

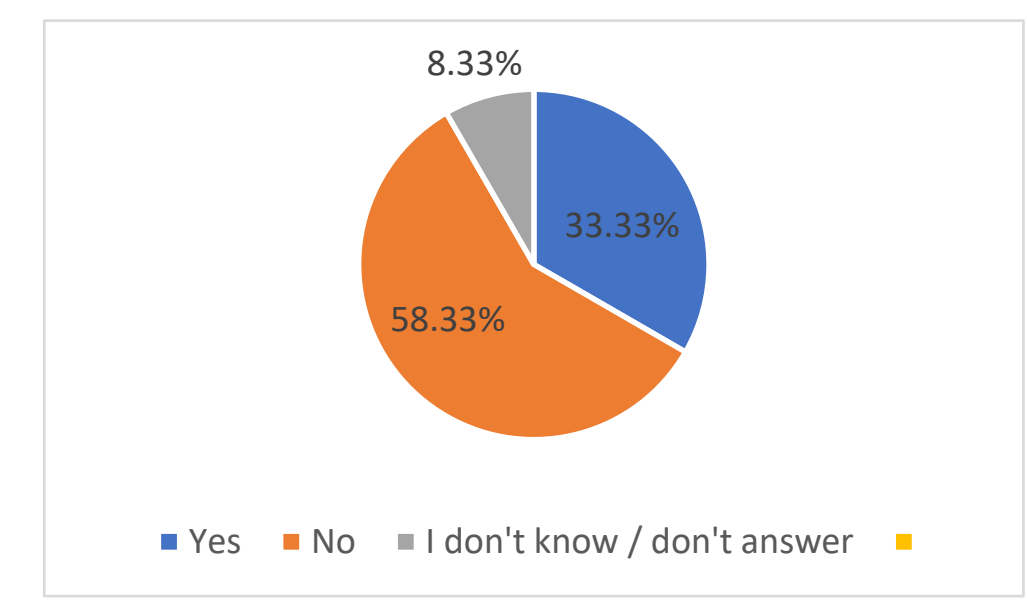

(Source: Authors Own Illustration Based on Chelcea, 2001)

Regarding item 5, taxation is considered fair and efficient by $33.33 \%$ of participants, $58.33 \%$ answered negatively, and $8.33 \%$ chose the option do not know/do not answer. More than half of the subjects question the fairness and effectiveness of this act. Thus, some of the hypotheses 
are validated, but it is important to identify solutions so that the degree of fiscal citizenship increases and the payment of the tax is seen as a right and not as an obligation. A system considered unfair and inefficient is not primarily credible. Only greater confidence in the tax system and decision-makers can lead to intrinsically motivated tax compliance, as appropriate. From the answers provided, it is difficult to say that each respondent, as a citizen-taxpayer, considers the payment of taxes a component of the relationship between him and local public authorities. Certainly, these percentages highlight the two sides of consent in fiscal matters: the legal one (the bodies empowered to establish them and adopt the necessary legislation) and the much deeper, socio-psychological one that considers the taxpayer and the degree of individual acceptance of the tax (Dominici, 2020). Greater attention should be paid to tax consent. A low degree of it weakens the fiscal power of local authorities, limits freedom of action and fiscal autonomy.

Respondents who preferred to choose the no option regarding the fairness and efficiency of taxation were asked to detail / specify what determined the choice. There is a deep sense of injustice and a lack of clarity about the final destination of taxes. I have selected for the present study a series of answers whose common denominator is distrust in the administration's ability to be truly in the service of the citizen:

- The laws do not apply equally, taxes... not even.

- We pay taxes for the salaries of those who are in management, as big as possible if possible... so we pay for their good, not ours.

- I only have obligations, not rights - that is how I feel like a citizen, and no one will convince me that things are different.

- As long as no one asks me, no one asks for my opinion on this issue, it only tells me what and how much I have to pay, I do not believe in the fairness of their establishment.

- I do not believe in 'fair' and 'efficient' because the practice and purpose of using these amounts show otherwise.

- 'Fish' and not 'sharks' are taxed. What justice and fairness are we talking about?

- For me, the tax means 'my money for them' not my money for me and those like me

- We pay taxes to support the salaries of some, not the community or if you want, some power 'communities.

- It is a way to cover the incompetence and indifference of decision-makers. It is clear, fair, and efficient... 
- The quality of the services provided is not commensurate with the amount of money I pay annually or in instalments, so it is neither fair nor efficient.

- As long as the money paid as taxes is reflected only in staff costs, I do not see what I should consider fair and efficient.

- I pay not for myself but for an administrative staff that does not live up to my expectations or the monthly salary received.

- For most of us they are high compared to salaries and pensions, and it does not seem to me that anyone would think about this.

- I am realistic... 300 lei taxes for an apartment means less than 10 lei per day, less than a pack of cigarettes costs me... but 300 multiplied by another 300 and another 300?!? was once an ad "Here's your money!" Really? Where???.

- Fair and efficient in one direction: to keep politicization and bureaucracy at alarming levels.

Following the analysis of the answers, it can be identified the factors that block the sincere and natural manifestation, from conviction, of fiscal citizenship: obligation, fiscal pressure, lack of decisional transparency, lack of a functional link-local tax administration-taxpayer (which can be extended to public administration at the national level), incompetence and administrative indifference, public services that lack quality, officials whose behaviour leaves much to be desired, tax evasion, discrimination, politicization, bureaucracy, public spending that lacks performance and control. It can be said that the list is exceedingly long, but there are solutions, some simple, if we were to quote Royer (2014), more political courage, "the only way to get efficiency and justice".

In what has been called the reform strategy, there is ample space for these problems, but giving does not mean solving them. Before building something physical and visible, the tax, its payment must create trust in public authorities. Another type of message is needed from the tax authority in communicating with taxpayers. The fiscal performance is the result of how individuals and legal entities pay their taxes voluntarily. But the taxpayers still perceive the relationship with the tax institution as one of power and not of partnership or oriented towards the tax system and not towards the citizen. The taxpayers appreciate the quality of the activity of the tax authorities depending on how the services are provided, how their needs and requests are met. Increasing trust and mutual respect are based on bringing together the interests of all participants in tax relations (Efremova, 2020). An oriented communication to the taxpayer, seen as a partner, customer, and beneficiary of these services will certainly increase the motivation for tax compliance. Fiscal 
citizenship and its defining elements can indicate the extent to which citizens feel defended by democracy and the rule of law. You cannot strengthen fiscal citizenship without strengthening trust in public authorities in terms of fiscal policy and taxation, without being responsible for the efficient use of the amounts collected.

The last item of the questionnaire received answers far below expectations. Given that $45.85 \%$ of respondents have higher education to the question Can you specify the final destination of the amounts you pay as local taxes? and the request If you answered yes, please specify I recorded the following: $26.66 \%$ of the respondents answered in the affirmative; $40 \%$ have the $n o$ option, and 33.33\% have the I don't know/don't answer option.

The specifications regarding the destination of the taxes were the following: salaries of the mayor's office employees / civil servants (specification present in 60\% of the questionnaires!), School/education, health, transport, the establishment of vaccination centers. The high percentage of those who chose the last two options denotes either lack of information, tax education, or selfeducation in this field, or these citizens do not feel any aspect of tax legitimacy even if they benefit from bonuses, exemptions, or deductions. To be motivated, but also to motivate, a good understanding of the functioning of the fiscal system is needed, of the local tax system in particular. Also noteworthy are the conclusions reached by Kirchler \& Braithwaite (2007) regarding the decision of citizens to cooperate with the state or its institutions and the willingness to pay taxes. While the economists consider relevant variables such as income, audit, tax rate, the severity of penalties or fines, the psychological research reveals equally important internal variables: the taxpayers' knowledge of taxation, the attitude towards government and the act of taxation, the personal values, how in which the social norms, the fairness, the motivation for compliance are perceived.

\section{Conclusion}

A first step that the local tax administration can take is to offer better quality services to meet the needs and personality structure of all taxpayers. Optimizing fiscal citizenship means responsible social behaviour concerning fiscal rules and equity, but also to issues related to the legitimacy of the tax located somewhere at the intersection of political, legal, administrative, and social. The power of fiscal decisions does not belong to the taxpayer; he is an actor without the possibility of direct involvement, hence the difficulty of being convinced of his role in the 
development of the local community and the fairness of taxation. Lewis (1978) noted that people have difficulty understanding tax law and that their knowledge of taxation is limited. Fiscal laws reflect very little of what it means the societal norms of fiscal behaviour or the fiscal morality, as an attitude. There is a close link between fiscal morality and civic duty. Orvisha \& Hudson (2002) considered that individuals are doubly motivated in adopting such attitudes: maximizing their wellbeing and a sense of responsibility towards society.

The significant improvement of the quality of the local tax administration-taxpayer ratio can become a guarantee of the fulfilment of fiscal obligations. It is also necessary a reorientate the taxpayers' vision: by paying taxes he buys a series of services that he could not cover or perform in his name: education, health, social protection, recognition, and guarantee of property, etc. From the administrative point of view, the interest of collecting the fiscal obligations prevails and not the one of transparency regarding the use of these amounts. It is necessary a culture based on rights and responsibilities, on the reciprocity of responsibility and the empowerment of the citizentaxpayer, their civic and political involvement, the increase of fiscal awareness. The payment of taxes formalizes the obligations we have to each other as members of a community (Mehrotra, 2015). In the opinion of the same author, the taxes, regardless of their type, define the duties and the obligations of the taxpayer, defining the status of the taxpayer. Fiscal compliance is synonymous with political and civic engagement (Mehrotra, 2015).

However, it must consider the current situation at the national and European levels. In the conditions of other waves of the COVID - 19 pandemics, it is necessary to create a stable and efficient fiscal system. The draft report of the European Parliament's Committee on Economic and Monetary Affairs in March 2021 emphasized the creation of a European socio-economic and environmental tax system that gave the European Union a chance to conduct a comprehensive analysis of tax assistance, how individual taxes interact and how they can be better coordinated to produce more flexible, resilient, and equitable tax systems. A new socio-fiscal contract with citizens is recommended for the Member States, which will increase revenue, strengthen trust and accountability in the citizen-state relationship.

There are several challenges for tax systems such as the need for public investment for economic recovery, the ageing and numerical decline of the working population, the digital transformation of labor markets, the intensification of tax competition, and existing tax damage. The financial environment is not optimistic. Companies, investors, financial markets, and 
everything that can be called regulatory authority are on a ground marked by uncertainty, risk, and unpredictability. Let us recognize as pointed out by Xiao et al. (2020) that the effects of the financial crisis have an impact on all sectors of the economy, that there are unresolved economic and political controversies on the cause and effects of the financial crisis. There are other issues related to taxation and tax collection; the tax burden is reoriented towards less mobile taxpayers, a situation that determines a lower average tax burden for taxpayers with extremely high incomes, which became possible after the transfer of tax incidence from the capital to income and consumption. The increasing mobility of taxpayers and tax bases will lead to stronger use of real estate tax bases, but government spending in the form of tax exemptions, tax deductions, loans, tax deferrals, and reduced tax rates is reflected in government funding.

The weak legitimacy of the tax can be solved by considering the taxpayer from a threefold hypostasis: partner-beneficiary and client of the local public tax service. I am convinced that in this way perceptions, attitudes, beliefs, behaviors will change radically. In a troubled world, solidarity is needed. A well-functioning local community will change the direction of national evolution. The tax is a reserve and a guarantor of local fiscal autonomy, but also of the freedom to choose freedom that I consider the essence of fiscal citizenship.

If considered the triangle of duties-rights-freedoms, C. Nabais (2009) stressed that fundamental rights presuppose the presence of fundamental duties, both related to the existence of the community, to obligations such as the defense of the homeland, taxes, and the payment of taxes. Freedoms depend on taxes and how they are spent. Rights depend on governments, but, according to Holmes \& Sunstein (1999), rights cost money! Rights cannot be guaranteed or protected without public funding and support.

\section{REFERENCES}

Allingham, M. \& Sandmo, A. (1972). Income Tax Evasion: a Theoretical Analysis. Journal of Public Economics. Volume 1. Issues 3-4. November 1972. 323-338.

doi.org/10.1016/0047-2727(72)90010-2

Bouvier, M. (2019). Tax without the citizen? Consent to tax, a crucial issue for democracy. Paris: L.G.D.J

Bouvier, M., Esclassan, M. \& Lassale, J.P. (2021). Public finances. 19th ed. Paris: L.G.D.J

Cathelineau, J. (1994). Local taxes. $2^{\text {nd }}$ ed. Paris: Dalloz-Sirey. 19 
Chelcea, S. (2001). Sociological research methodology. Quantitative and qualitative methods. Bucharest: Economic Publishing House

Dincă, D. (2013). Local public services - evolution and reforms. Bucharest: C.H. Beck Publishing House

Dominici, L. (2020). Towards a "new form" of tax consent to sustain democracy. Management \& Public Finances/Lavoisier. no. 6. 78-83. https://doi.org/10.3166/gfp.2020.6.011

Dubois, J. (1972). Psychoanalysis of the taxpayer. Paris: Project. 145-154

Efremova, T.A. (2020). Developing tax administration in the context of the partnership of participants of tax relations. 3C Empresa. Investigación y pensamiento crítico, 9(3), 109123. https://doi.org/10.17993/3cemp.2020.090343.109-123

El Ghazali, M. \& Benkendil, H. (2020), Tax citizenship: How can a climate of trust be established between the tax administration and the taxpayer?. International Journal of Accounting, Finance, Auditing, Management and Economics. 1(2). 423-440. https://doi.org/10.5281/zenodo.4027815

Freund, A. (2019). Western Corporate Fiscal Citizenship in the 21st Century, Northwestern Journal of International Law \& Business, no. 40:123, https://scholarlycommons.law.northwestern.edu/cgi/viewcontent.cgi?article=1851\&conte $\underline{\mathrm{xt}=\mathrm{njilb}}$

Gilbert, G. (2001). Fiscalité. Dictionnaire des sciences économiques. PUF

Holmes, S. \& Sustein, C.R. (1999), The Cost of Rights: Why Liberty Depends on Taxes. 1st ed. New York: W.W. Norton \& Co Inc

Katz, J.P., Ott, R.L. (2006). If we could choose the way we Pay: The impact of decision complexity on tax scheme preference. no. 22(3). 33-42. https://core.ac.uk/download/pdf/268103732.pdf

Kirchler, E., Braithwaite, V. (2007). The Economic Psychology of Tax Behaviour. Cambridge: Cambridge University Press. https://doi.org/10.1017/CBO9780511628238

Lambert, T. (2013). Fiscal procedure. 2nd ed. Paris: L.G.D.J. 110

Lewis, A. (1978). Perceptions of tax rates. British Tax Review, no.6, 358-366

McGee, R. (2006). Three Views on the Ethics of Tax Evasion. Journal of Business Ethics. no. 67. 15-35. https://doi.org/10.1007/s10551-006-9002-z 
Mehrotra, A.K. (2015). Book Review. Reviving Fiscal Citizenship. Maurer Faculty. 1662. https://www.repository.law.indiana.edu/facpub/1662

Orviska, M., Hudson, J. (2003). Tax evasion, civic duty and the law-abiding citizen. European Journal of Political Economy. no. 19(1). 83-102. https://doi.org/10.1016/S0176$\underline{2680(02) 00131-3}$

Prak, M.R., Zanden, Jan. (2013). Tax Morale and Citizenship in the Dutch Republic. The Political Economy of the Dutch Republic. https://www.researchgate.net/publication/46722178_Tax_Morale_and_Citizenship_in_th e_Dutch_Republic

Ranta, A.E. (2016). Identifying barriers, deficiencies and needs to improve institutional communication in public administration. The role of public relations in this context. Transylvanian Journal of Administrative Sciences. no. 2(39). 184-205

Royer, D. (2014). Control of public services: the LOLF. After tomorrow. 29, NF, 19-21. https://doi.org/10.3917/apdem.029.0019

Similien, J.M. (2017). Tax citizenship: culture to promote. https://lenouvelliste.com/article/178532/civisme-fiscal-la-culture-a-promouvoir

Spire, A. (2018). Resistance to taxation. Attachment to the State. French taxpayer survey. Paris: Seuil. EAN 9782021367683

Toader, L. (2013). Financial, fiscal, budgetary policy - points of view. București: Top Form Torgler, B., Murphy, K. (2004). Tax Morale in Australia: What Shapes it and Has it Changed over Time?. CREMA - Center for Research in Economics, Management and the Arts. Paper No. 2004-04. Zürich. https://www.econstor.eu/handle/10419/214290

Xiao, L., Dhesi, G., Ceptureanu, E.G., Lin, K., Herteliu, C., Syed, B. and Ceptureanu, S.I. (2020). Liquidity transmission and the subprime mortgage crisis: a multivariate GARCH approach. Soft Comput 24. 13871-13878. https://doi.org/10.1007/s00500-020-04772-4

Zai, P.V. (2014). Modern approaches to budgetary policy: fiscal policy and public spending policy. Transylvanian Journal of Administrative Sciences. 1(34)2014, 113-124. https://rtsa.ro/rtsa/index.php/rtsa/article/view/475/472 